\title{
Henning Goldbak
}

\section{Glemselens melankolske blomst}

\author{
Om den centraleuropæiske kultur i tyverne - med \\ udgangspunkt i Milan Kunderas forfatterskab.
}

En af de mest produktive og aktualiserende repræsentanter for den centraleuropæiske kultur lige nu er den tjekkiske eksilforfatter Milan Kundera. I sine filosofiske romaner og mange essays peger han hele tiden bag om efterkrigsmodernismen og tressermarxismen tilbage til værdiforfaldets forfattere og tænkere fra begyndelsen af det tyvende århundrede, Hermann Broch, Robert Musil, Kafka og Freud. Med udgangspunkt i Kunderas fremstilling af deres og hans fundamentale diskussion af Vesteuropas fælles identitet, fornuft og fremskridt, opridses i det følgende de divergerende opfattelser, hos Hugo von Hofmannsthal, Musil og hos Walter Benjamin, hvis tidlige forfatterskab mister sin aura af okkultisme og raritetsbutik, hvis det læses ind i den centraleuropæiske baggrund, som Benjamin i trediverne tog afstand fra med en reddende intention.

Milan Kundera er blevet kendt i Vesteuropa de sidste ti år, ikke kun på grund af sine romaner, der er oversat til de fleste europæiske sprog, ${ }^{1}$ men lige så meget, fordi han i næsten ethvert større litterært tidsskrift har genoptaget en debat om centraleuropæisk kultur, der ifølge ham egentlig sluttede i 1930'erne, da den blev bremset af den politiske udvikling i Tyskland og i Sovjetunionen, af den Anden Verdenskrig og den kolde krig. Med centraleuropæisk kultur mener Kundera ikke mellemeuropæisk kultur, der for ham er centreret om tysk kultur og dens udbredelse, men en kultur der geografisk hører hjemme i landene omkring det nuværende jerntæppe: Polen, Tjekkoslovakiet (som Kundera altid kalder Bøhmen), Ungarn, Rumænien, Øst-

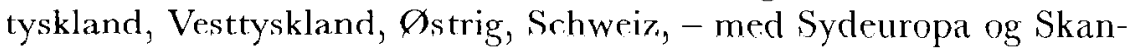


dinavien som randområder. Engang, siger Kundera, foregik der en naturlig udveksling af meninger, især, og af varer mellem øst og vest; hvornår er lidt uvist, han har flere forklaringer. Nogle gange er Centraleuropa identisk med det hedengangne Donaumonarki, så gik det altså under i 1918. Andre gange omfatter det mere en holdning til Europa end et sted, altså en særlig holdning, der søger at formidle mellem Vesteuropa og Østeuropa, hvor Vesteuropa er: kristendom med Rom som centrum, humanisme, renaissance, oplysningstid; Østeuropa er Byzans, ortodoksi og urokkelige traditioner. Øst er hos Kundera altid Rusland, kaldet Det russiske Rige. ${ }^{2}$

Kunderas forklaring på denne naturlige vekselvirknings krise er derimod mere entydig. Den knytter sig til tre årstal: 1938, 1948 og 1968, Hitler og Stalin, München og Prag. Tanken hos Kundera er, at de omtalte små og mindre lande godt kunne have en vis vekselvirkning, indtil de blev opsuget af de to store systemer, Rusland-Sovjet, Tyskland som eet land, og senere af øst og vest. Den naturlige vekselvirkning kunne ideelt finde sted i et Tyskland, der bestod af småstater og i Donaumonarkiets flerstatssystem, som Kundera aldrig undlader at fremhave som model for fremtidens statsdannelser. ${ }^{3}$

Den centraleuropæiske kultur går ifølge Kundera nok under på grund af den tyske udvikling, men først og fremmest på grund af Det russiske Riges ekspansionslyst. Og det dækker alt fra zarisme og dens fortsættelse som stalinistisk ekspansion. Kundera nævner dels panslavismen (alle russere er slavere, alle slavere er russere) og tesen om socialisme i eet land, nemlig Sovjet, der så eksporterede sin særlige russiske statsform til Polen, Tjekkoslovakiet osv. efter 1945, eksempelvis i 1948 og igen i 1968. I den dobbelte proces, Tysklands og Sovjetunionens udvikling, blev de små lande kvast, der lå midt imellem, de store kjødiske befolkningsgrupper forsvandt og vekselvirkningen holdt op. Industrialisme og fremskridt satte sig igennem på hver sin måde i øst og i vest, siger Kundera. Men de opslugte småstater i det nuværende Østeuropa sætter fortsat spørgsmålstegn ved den store historie i Europa; de er udviklingens dårlige samvittighed.

Det vil sige, at centraleuropæisk kultur betyder to ting. Dels en traditionel vekselvirkning langt op i sidste århundrede. Og derpå en moderne krisebevidsthed, hvor det spørgsmål stilles: om Europas identitet, fremskridtstanken og oplysningen gælder mere? Imellem midten af det nittende århundrede og 1930'erne er den centraleuropæiske kultur i stigende grad i opposition til den politiske udvikling, og til enhver officiel statskultur, der forherliger harmoni og totalitet. ${ }^{4}$ Den centraleuropæiske kultur som krisefænomen er i bund og grund betragtende og skeptisk, tvivlende og prøvende. Et nøgleord for den er 
interesseløsheden. Det vil sige at dens verdensfortolkning og dens æstetiske horisont ikke er bundet til naturbeherskelse og politisk beherskelse. Det betyder ikke, at den forlader oplysningens horisont, tværtimod. Den er medierende, den fastholder hele tiden, at der nok skal tænkes hen mod en helhed, men en helhed uden konklusion. ${ }^{5}$

Der har været rettet den anklage mod Kundera, at hans kulturbegreb blot er Menneskets estetiske Opdragelse igen, at det blot udtrykker et par tusind åndspersoners ønske om, at der skal stå en talerstol parat i Budapest, med publikum foran, når man kommer fra Danmark, og omvendt. ${ }^{6}$ Men Kundera mener ikke kun finkultur med sit begreb. Kultur er det eneste sted ifølge ham, hvor der rettes en kritik mod den eksisterende politik. Hans essays og romaner er ganske vist utrolig kulturelle i deres horisont, (Gervantes, Dante, Husserl, Schönberg mm.), men de reflekterer altid en utrolig bred historisk og politisk udvikling i Europa, og de peger stædigt og med stor tydelighed på den europæiske histories ømme punkter, netop dem, der er omtalt her.

Man kunne snarere spørge Kundera, hvorfor han genoptager en diskussion og fastholder en kulturel horisont, når han samtidig siger, at den er holdt op for 40-50 år siden? Hans svar er nok, at hans begreb er aktuelt, sålænge det peger på den store histories omkostninger. Netop dette, at Centraleuropa er gået under og kun findes som hukommelse om tvang, er diskussionens berettigelse. Hvad er en europæer? spørger han i Romankunsten. Og hans svarer: én der længes tilbage efter Europa. ${ }^{7}$ Men hans svar og hans stædige insisteren er samtidig en bestemt sprog-problematik, der kommer til syne i Bogen om Latter og Glemsel, hvor den gamle Beethovenforskers tekst bliver uforståclig, fordi han bruger ord, der slet ikke findes. Men de gængse ord glemmer han. ${ }^{8}$ Sprogproblematikken er udfoldet i Kunderas essay om Cervantes. ${ }^{9}$ Typisk nok er der tale om en bekendelse både til Don Quixote og til Sancho Pansa. Altså både til forvalteren af de store tanker og til den bagvedridende skepsis, der prøver at redde Don Quixote fra de værste ulykker. Overført på en sprogproblematik bliver denne dobbeltholdning til en spænding mellem begreber og det der falder udenfor, det ikke-identiske. Denne spænding kan dels ophøre, fordi det konkrete dominerer, som hos den gamle forsker, der kun kan sige: det er underligt. Men den kan også ophøre fordi ideerne sejrer over det ikke-identiske, og resultatet er tilvarelsens ulidelige lethed. ${ }^{10}$

Kunderas roman Tilverelsens ulidelige Lethed fra 1984 handler om at blive afvænnet fra de store ideer som livsgrundlag, for hele lande og for enkeltpersoner. For det er netop dem, der gør tilværelsen ulidelig 
let. Bogen har ikke et, men to kærlighedspar, hvis forskellige udvikling man følger. Det ene par debatterer kommunismen som en del af deres forhold. De lever i Vesten. Det andet, centraleuropæiske par bor i Prag og senere på landet. Tomas og Teresa lærer hinanden at kende før Pragerforåret 1968. Som et udtryk for deres optimisme køber de Beethovens strygekvartetter. De hører først og fremmest den seneste, opus 135, hvis sidste sats indeholder to temaer, bygget over henholdsvis: muss es sein og es muss sein, som et udtryk for Beethovens faste tro på det borgerlige samfunds fremtidsmuligheder. Efter den forenede invasion i august 68 flygter Tomas til Zürich, han er læge, og finder arbejde på et hospital. Han beslutter sig imidlertid til at vende tilbage til Prag og til Teresa. I afskedsscenen med den schwiziske overlæge, der har ansat ham, siger Tomas: es muss sein. Men lægen kender Beethoven, og nynner: muss es sein? og Tomas svarer nynnende igen: es muss sein. I løbet af romanen vender citatet tilbage, i takt med, at den Beethovenske optimisme afskrives til fordel for afviklingen af politik, storby og fremtid i det officielle, statslige regi. Tomas og Teresa flytter på landet, kun til dels nødtvungent. I romanens slutning kører parret sammen med andre beboere fra landsbyen til nærmeste provinsbys danserestaurant, for at danse, ikke til Beethoven, men til populærmusik fra tyverne og trediverne. Denne udvikling er ikke kun flugt og naturdyrkelse, selvom de to taler om, at de lever i en idyl, hvor tiden som udvikling er erstattet af tidens gentagelse. De er især havnet på landet, fordi Tomas i en ægte Beethovensk holdning nægtede at dementere et systemkritisk læserbrev fra "foråret «, som betingelse for at beholde sit lægejob i Prag plus diverse privilegier. Der gemmer sig ikke kun nostalgi og inderlighed i idyllen, men også hårdnakket politisk protest, es muss sein."

Men denne heroiske holdning står ikke alene i romanen. Beethoven dukker op i en overraskende sammenhæng. Vi făr baggrundshistorien for ordskiftet. Beethoven gik en dag op til sin musikforlægger, for at få forskud/honorar. Muss es sein, sukkede forlæggeren. Es muss sein, svarede Beethoven, og han gik derfra med sine penge. Derhjemme lavede han af glæde et lille musikstykke for fire stemmer. De tre sang: es muss sein, es muss sein, ja, ja, ja. Den fjerde sang: heraus mit dem Beutel. Først senere brugte Beethoven temaet i sin sidste strygekvartet, hvor sætningstemaet fik sit heroiske udtryk. I romanen overvejer Tomas, at Beethoven også kunne have gjort det omvendte. Han kunne være gået hjem fra forlæggeren, have skrevet den dybsindige kvartet, og derefter den muntre version for fire sangstemmer. Han kunne have bevæget sig fra det tunge til det lette. Men det ville publikum ikke have glædet sig nær så meget over, tilføjer Tomas. Publikum og 
offentlighed, borgerlig eller statssocialistisk, vil have adel kunst, og Kunderas begreb, ikke for Beethoven selv, men for klassisk-romantisk kunst som forherligelse af det tyvende århundredes systemer, er ordet Kitsch. $^{12}$

Den sætning, der gemmer sig bag Tomas' omvendingsfantasi i relation til Beethovens musik, er ganske vist afledt af: es muss sein. Den lyser: es könnte auch anders sein. Det betyder, at romanen skildrer bevægelsen fra Beethovens utopi til socialrealisme og til Tomas' heroiske brug af Beethoven, ved siden af omvendingsfantasien. Ikke sådan, at en af synsvinklerne skal sejre; men sådan, at romanens form rummer Tomas' omvending ved siden af den gamle Beethovens sætning. Altså sådan, at romanens form er essayistisk åben, ikke stilende hen mod en bekræftende coda. ${ }^{13}$

\section{II}

Sætningen: es könnte auch anders sein viser tilbage til Robert Musils roman, Manden uden Egenskaber, der blev påbegyndt i 1922 og efterladt ufuldendt ved Musils død i 1942. Sammen med Hermann Brochs Søongengerne og Vergils død er Musils bog nok den mest overbevisende sammenfatning af hele den centraleuropæiske kulturelle tænkemåde, og på samme tid dens afslutning. Manden uden Egenskaber handler om forberedelserne til jubilæumsfesten i 1918 for den østrigske kejser, og samme forberedelsers skrinlæggelse ved forste verdenskrigs udbrud i august 1914. Første verdenskrig er en nøglebegivenhed for de centraleuropæiske forfattere i tyverne. For dem var den store krig det synlige bevis på, at Europas civilisation var slået fejl. Den udvikling, der var anet og spået før første verdenskrig, slår tydeligt igennem efter krigen, og lader de forskellige kunstnere fortsætte deres opgave: at beskrive og udtrykke det irrationelle, som de ofte kalder det. De, det er Hofmannsthal, Schnitzler, Thomas Mann, Kafka, Rilke, Schönberg, Berg, Mahler, Stefan Zweig, Freud mm. ${ }^{14}$ Med det irrationelle mener de, sådan har Carl E. Schorske forklaret det i sin bog om Wien ved århundredeskiftet, Fin de Siècle Vienna, det som unddrog sig det liberale borgerskabs fremskridtshåb og klassiske-Beethovenske jegopfattelse. ${ }^{15}$ I lyset af første verdenskrig, og allerede før, for eksempel på grund af de tiltagende nationale spændinger og angreb på liberalismen, begyndte forfattere som Hofmannsthal og Schnitzler at stille sig selv den opgave, at de ville/måtte anspænde deres formsprog, indtil det kunne rumme de uforklarlige huller i fornuftens udvikling. 
Hos Hofmannsthal kom det blandt andet til udtryk i det såkaldte Chandos-brev fra 1902. Brevet er henlagt til renaissancen, skrevet af en ung engelsk adelsmand med al klassisk baggrund, og det er stilet til Francis Bacon, filosoffen og videnskabsteoretikeren. Brevet handler om muligheden for at udtrykke sig inden for rammerne af dannelse og fornuft. Det som ikke kan være i dette sprog for Chandos, bliver løsrevne ting, hæslige, spolerede eller bare kedelige-almindelige ting, som han væmmes ved og føler afmagt overfor, fordi de er påtrængende og førsproglige. Men det er et tegn på sprogteoriens paradoks, at det bedste eksempel på det, der ikke kan udtrykkes, netop hentes fra den klassiske, latinske tradition, som ellers er gjort afmægtig overfor det fragmentariserede. Det billede Chandos bruger for at forklare sig, handler om en romersk senator, der var så forelsket i en husfisk, at han græd af sorg, da den døde. Det der ikke kan udtrykkes rent, må udtrykke sig i det gængse begrebssprog som middel, således bliver Hofmannsthals konklusion på sprogkrisen, og sådan er holdningen $\mathrm{i}$ hans senere forfatterskab, hvor han blandt andet samarbejder med Richard Strauss. ${ }^{16}$ Det vigtige i hans værker er ikke det glatte og elegante sprog, men det fortrængtes diskrete tilsynekomst som attituder og gestik snarere end som mening. Chandosbrevet har en parrallel i Schönbergs næsten samtidige kritik af ornamentet indenfor musikken til fordel for de direkte, psykiske udtryk, for eksempel de berømte angstakkorder i Erwartung og Die glückliche Hand. Men ligesom Schönberg meget snart vender tilbage til musikalske gentagelsesstrukturer og storformer i musikken (for eksempel rondoen), så vender Hofmannsthal tilbage til det standpunkt, at det helt enkeltstående og uformidlede må udtrykke sig gennem fællessproget.

Denne dobbelthed overtager Musil, men han formulerer den meget skarpere, og på et langt mere alment plan end Hofmanns thal, for slet ikke at tale om meget wienske forfattere som Schnitzler og Bahr. Mens Hofmannsthal med pietet efter Første Verdenskrig prøver at uddrage essensen af den centraleuropæiske tankegang, ved at restaurere Dobbeltmonarkiets katolske verden som et drømmebillede, så går Musil ubønhørligt til værks. Hans konklusion efter krigskatastrofen efterlader intet håb om tilbagevenden. Som udtryk for mellemkrigstidens afregning med den centraleuropæiske horisont står Musil markant som dens ideologikritiker. Alle ideologier latterliggøres, nationalismer, katolicisme, kapitalisme, socialisme på kapitalistisk eller på katolsk baggrund, Nietzsche, Maeterlinck og dermed også Hofmannsthal. Romanen Manden uden Egenskaber består hovedsagelig af karikaturer, hvilket man kan høre blot udfra de klicheagtige navne med deres litterære referencer eller barokke sammensætninger: 
Diotima, Meingast, General von Bordwehr, Ermelinda Tuzzi, Soliman og Arnheim; samt navnet på Kejser- og kongeriget, Kakanien. Denne kritik foretages i bogens første og anden del, som udkom i begyndelsen af trediverne, uden at vække større opsigt, nok snarere modvilje i det tysk-nationale Østrig, på grund af sin skarpe kritik og på grund af forfatterens markant intellektuelle tænke- og skrivemåde.

Man har i høj grad hæftet sig ved første del af Musils roman, også efter den sidste krig, og brugt den skeptiske tendens i den til at afskrive Musil som handlingslammet licentiat. Man har sagt, at hans skepticisme var så radikal, at den udelukkede et alternativ til det, der blev kritiseret. Men det er forkert. Den beskrivelse passer meget bedre på den omtalte Schnitzler, og kan studeres i hans roman Der Weg ins Freie. Manden uden Egenskaber, dens sidste to trediedele er et tydeligt forsøg på at udforme en utopi. Bogens sidste kæmpeafsnit, der aldrig blev fuldendt, hedder Ind $i$ Tusindårsriget, med talrige henvisninger til den tyske romantiks ny mytologi. ${ }^{17}$

I bogens sidste hovedafsnit erstattes kritikken af medieringsforsøg, af skabelser. $\mathrm{Og}$ her træder romanens hovedperson, Ulrich frem og bliver handlende på baggrund af de ideologier han har endevendt, faktisk dissekeret. Men selvfølgelig bygger han ikke nye ideologier op. Romanen skulle oprindelig have heddet Monsieur le Vivisecteur, men kom til at hedde Manden uden Egenskaber. Uden egenskaber betyder i romanen, at være uden det tidlige, borgerlige samfunds jegstruktur. Jeget hos Ulrich er ikke et syntetiserende midtpunkt for erkendelse og handling, men gennemgangssted for funktioner, bevægelser, impulser og strømme. I den grad, at Musil et sted har kaldt sin roman for: egenskaberne uden mand. Hele tankekomplekset går tilbage til Ernst Mach, den østrigske filosof, som Musil skrev doktordisputats om. I forlængelse af Mach skelner Musil mellem jegets praktiske vane med at gå ud fra gentagelse og kausalitet i sine iagttagelser, altså sådan at et aktivt ordnende jeg står ovenover et kaos af indtryk, som det ordner: og heroverfor det virkelige forhold, at dette iagttagende og syntetiserende centrum ikke findes, altså sådan at der i virkeligheden ikke er en afgørende forskel på jeg og omverden, men kun funktioner, der kan varieres i det uendelige.

En overgang prøver Musil faktisk at bygge sin kunstteori på en ren funktionsteori, det vil sige en ren betragtende-æstetiserende fremgangsmåde, med kunstneren som naturvidenskabsmand, iagttagende. Der er mange træk af denne holdning i Den unge Törless, og et af de mest berømte eksempler er en lille prosaskitse med titlen Fluepapiret, som handler om fluens (jegets) kamp mod det overmægtigt bindende fluepapir, indtil den ikke har flere kræfter og vælter om på siden som 
en hest. Men selv efter at fluen er død, er der stadig et lille flimrende organ på et af benene, der bevæger sig; det åbner sig og lukker som et lille bitte menneskeøje. ${ }^{18}$ Selv her bryder Musil med en ren funktionstænkning, slutningens som om åbner mulighed for at jeget ikke er helt dødt. Det spørgsmål Musil stillede sig i stigende grad, mens han skrev Manden uden Egenskaber, især den sidste del, var spørgsmålet, om hvordan han kunne udforme en utopi, der ikke blev til ideologi, ligesom alle dem han havde brugt Machs filosofi til at kritisere. Hans svar er, at det kun kan ske i kunsten, der stadig kan anvende det videnskabelig-rationelle sprog side om side med det poetiske: Musils utopi findes i de sprækker, der er mellem begreb og billede, videnskabelig sprog og poetisk sprog, mellem sammenligningens to dele. Hans utopi kommer til udtryk i et særligt formbegreb, hentet fra gestaltteorier; essensen af formbegrebet er, at dele, eksempelvis forskellige typer sprogbrug, skifter betydning, når de indgår i nye helheder, og bliver glidende, svævende og ikke fastdefinerede. Kunstens som om gør, at et kunstværk kan forene modsætninger, så de bringer nye muligheder i forhold til deres sædvanlige rolle som kendsgerninger. Utopien hos Musil forudsætter en demontering af kendsgerninger, de skal først brækkes ud af deres nødvendighed og underkastes fantasien, som derpå kombinerer dem til nye muligheder, til mere end funktioner og til mindre end et hierarki. Eksempel:

Et klassisk ophøjet maleri; en jæger i den grønne skov skyder en ædel hjort, der farer i vejret og knækker sammen og styrter omkuld. Sådan ser motivet ud på mange hotelmalerier. Men, siger Musil, så snart vi tænker os billedet i en anden rækkefølge, har vi også i kunsten som medium peget på muligheden af en anden sammenhæng end den traditionelle, hvis vi nemlig omvender billedet. Altså, hjorten må op på benene, ned på benene, og leve igen, og kuglerne må tilbage i geværet sammen med krudtrøg og slam. ${ }^{19}$

Dette eksempel står i sin intention i umiddelbar nærhed af Kunderas Beethoveneksempel, og med ham deler Musil også den grundholdning, at den utopiske formulering er henvist til den verden og det sprog, den ellers kritiserer som forældet eller som værende for almen. Deres formbegreb og utopi indebærer, at hele processen er med i deres bøger: ideologi, kritik af ideologi, og muligheden af at tænke sig noget andet. Derfor sker der typisk det i deres bøger, som General von Bordwehr så udmærket beskriver i Manden uden Egenskaber. Generalen prøver at inddele de intellektuelle efter hærenheder, under salondiskussioner. Men til hans store rædsel sker der ombytninger, desertationer, fronterne går i opløsning. Meninger og formelementer, der netop er blevet aflivet, genopstår og lever videre, som mulighe- 
der. Måske kan man sige, at holdningen hos Kundera og Musil, som er den centraleuropæiske kulturs grundholdning, egentlig er den samme som grundforskningens, der ikke er afhængig af resultater og mål, men har frihed til at prøve alt for at nå frem til andre resultater. I Manden uden Egenskaber angår dette træk for eksempel fortælleformen. Selvom den er overskuelig og vidner om overblik, så er jo overblikket, det jeg der kan have et overblik, detroniseret af Musil. Men ved siden af Machs egenskabsløse jeg har Musil indført et andet jeg, uden egenskaber, men i stand til at strukturere, altså et produktivt jeg, som absolut ikke kan rummes i Machs jegdefinitioner, som de er beskrevet af Musil. Om fortællerens rolle hedder det i Manden uden Egenskaber:

\footnotetext{
Held den, der kan sige »da«, »for « og »bagefter«! Han kan have været ude for noget slemt, eller han kan have vredet sig i smerte, men sả snart han er i stand til at gengive begivenhederne $\mathrm{i}$ deres tidsmæssige forløbs rækkefølge, føler han sig så vel, som om solen skinnede på hans mave. Det er dette, som romanen kunstigt har benyttet sig af: den rejsende rider måske $\mathrm{i}$ øsregn ad landevejen eller stamper i tyve graders kulde gennem den knirkende sne, læseren bliver behagelig til mode... De fleste mennesker er fortællere i det fundamentale forhold til sig selv... De holder af det ordnede Nacheinander af fakta, fordi det ligner en nødvendighed, og føler sig ligesom i sikkerhed midt i kaos gennem det indtryk, at deres liv har et »løb«. Og Ulrik bemærkede nu, at han havde mistet dette primitivt episke, som det private liv endnu holder fast ved, selvom i det offentlige alting allerede er blevet ikke-fortællende og ikke længere følger en »tråd«, men udbreder sig $\mathrm{i}$ en uendeligt sammenvæevet flade. ${ }^{20}$
}

Den uendeligt sammenvævede flade er formbegrebet og utopien. De traditionelle billeder og det primitivt episke er egentlig afskaffet, men her bliver de pludselig genoplivet som den mulighed der er mellem deres gamle dominans og deres reduktion til ren ideologi. De bliver genoplivet, idet de bliver nævnt som overståede fænomener; læst i romanens helhed giver det den virkning, at de gamle ideologier blandes igen og indgår $\mathrm{i}$ en uendelig syntetiserende proces af sammenkoblinger, der ophæver værdier og skaber nye. Denne fremgangsmåde ligger i forlængelse af den progressive universalpoesi hos Schlegel og Novalis, også i det forhold, at processen er foreløbig. Manden uden Egenskaber kunne ikke afsluttes.

I begyndelsen af Musils roman går to personer tur i Wien, de føler sig som jeg-centre, men kun i deres egen bevidstheds fine undertøj, som der står. I virkeligheden er de kun seismografer for byens uregelmæssighed, forandringer, sammenstød af ting og begivenheder. Da der sker en bilulykke i deres nærhed, en mand køres ned, ambulancen kommer, så afsløres det i et chokagtigt øjeblik, at noget truer deres opfattelse af sikkerhed og distance; de føler kvalme og rådvildhed, 
står der, som de prøver at finde ord for: medlidenhed; men ordet dækker ikke deres kaos-oplevelse. For den, der kan føle medlidenhed, har jo en fast afgrænset position, som gør ham stærk nok til at føle med andre. Musil standser imidlertid ikke i denne analyse af de to personer. "Tror De han er død? «, spørger kvinden. »Jeg håber, at han lever«, svarer herren. "Sådan så det ihvertfald ud, da man løftede ham ind i vognen. « $^{21}$ - På eet plan er dette kun klicheer, som medlidenheden. Det de to personer siger i situationen, dækker over deres rådvildhed. Men samtidig er klicheen, efter at være demaskeret som rationalisering, pludselig autentisk genbrugt, den bliver til et eksempel på mulighed. Måske er manden, der blev kørt ned, stadig levende. Eller måske håber de to faktisk, at det må være tilfældet, og der trods alt findes en mening, selvom det jo ellers er dementeret $i$ beskrivelsen af storbyens almagt over individerne.

Det var dette enorme omfortolkningsarbejde med at slå muligheder og åbenhed af klicheer og begreber, som Musil brugte de sidste år af sit liv på, mens han levede i det neutrale Schweiz. Set i dette perspektiv af radikal, men også af utopisk formulering på baggrund af et værdiforfald i Europa, så står Musil og Broch tæt på hinanden. Samme afvikling af alle prægede meninger ned til et nulpunkt, og derpå genskabelse og ny betydning til erstatning for de forfaldne værdier. Denne sammenhæng og intention er muligvis først blevet tydelig efter udgivelsen af Musils samlede værker for nogle år siden, med alle fragmenter og noter til Manden uden Egenskaber. Måske er der desuden en historisk grund til, at netop han så længe har været betragtet som den altfor intellektuelle og skepticistiske. Musil blev oversat og læst i slutningen af tresserne, og betydningen af utopi har ændret sig siden studenteroprøret. Dengang var det svært at se $\mathrm{Mu}$ sils bestræbelser som utopiske, fordi de var kulturelle, litterært-sproglige, og ikke politisk-emancipatoriske, for det første. Og fordi de ikke var jublende fremtidsrettede, men tværtimod sirlige og lirkende bearbejdelser af forstenet betydning og fortid til åben nutid, sådan at fortidens materialer er fremtidens muligheder.

\section{III}

Der findes imidlertid også eksempler på tænkere, der i deres afregning med den centraleuropæiske tradition tog afstand fra hele dens kulturelle horisont, for at videreføre dens tankegods i en venstreorienteret, marxistisk sammenhæng. Det er tilfældet hos Lukács, fra Roma- 
nens teori, Sjelen og Formerne til Historie og Klassebevidsthed (1923). Det er tilfældet hos Ernst Bloch, der ændrer førsteversionen af Andens Utopi (1918) fra at være en ekspressionistisk-religiøs traktat, til en reddende-marxistisk bog i 1923-udgaven. Her indfører han det afgørende begreb om Vorschein, det vil sige, at den før-marxistiske historie aldrig kan tages for pålydende, den udtrykker sig altid i ideologiske former, hvor det så er ideologikritikeren Blochs opgave at skelne mellem ideologi og utopisk substans, som det der skal reddes. I forlængelse af Blochs intention kan Walter Benjamins forfatterskab ses, med den klare forskel, at Benjamin altid mistænkte Blochs partihørsforhold for at være en belastning for en reddende og ikke kun ideologikritiskreddende filosofi.

Den centraleuropæiske kulturs utopi om redning af det ikke-identiske i historien, dens formidling mellem fornuft og irrationalitet, skal formuleres politisk som en del af klassekampen, og ikke som kultur, siger Benjamin omkring 1930, efter selv at have været en del af miljøet, for eksempel i sit samarbejde med Hofmannsthal indtil dennes død i 1929. I modsætning til Lukács og Bloch bliver Benjamin stående forbavsende længe indenfor den centraleuropæiske kulturs horisont. Det hænger bl.a. sammen med hans dybtgående opgør med tidens filosofiske hovedretning, nykantianismen, især i dens scientistiske form hos Hermann Cohen. Benjamins opogør med nykantianismen blev speciel kompliceret, fordi han så dens systemtenkning som et symbol på hele sin periodes tænkning, historieopfattelse, politik, også på venstrefløjen. Han havde derfor langt sværere ved at vælge marxismen som alternativ end tilfældet var for Bloch og Lukács. Den centraleuropæiske tænknings horisont med dens skeptiske grundholdning overfor rationaliteten og den kulturelle horisont med rødder tilbage til romantikkens kunstkritik, var langt mere tillokkende for Benjamin. Men efter, som filosof, at have udviklet en litterær-billedrig, barok skrivestil i bogen om Kunstkritikken $i$ den tyske romantik (1919), i sit essay om Goethes Valgslegtskaber (1922), og især i sin bog om allegorien i det barokke sørgespil (1924), så træder Benjamin ud af værdiforfaldets horisont, (Barokbogens emne), i slutningen af tyverne. Han forlader det han selv har kaldt den germanistiske produktionskreds. Man plejer at sige, at han derefter blev marxist, fordi han ikke kunne få job på universitetet, og fordi hans velhavende far blev fattig under inflationen i tyverne. Men det er mindst lige så vigtigt at henvise til den grund han selv giver i trediverne i det berømte essay om kunstens reproducerbarhed, hvorefter overbygningen nu, på Benjamins tid, er underlagt den kapitalistiske produktions og reproduktions betingelser. Man kan sammenholde hans handling med mange 
af de andre centraleuropæiske tænkeres: de reagerede ofte med elitære, hermetiske, selvstiliserende træk, da det gik op for dem, at kapitalismen ikke gjorde holdt ved den centraleuropæiske kulturs tempel. Benjamin bruger derimod erkendelsen af det kulturelle områdes profanering til (i princippet) at gøre som Bloch: at redde den centraleuropæiske kulturs medieringsbegreb over $\mathrm{i}$ en politisk ramme, og $\mathrm{i}$ øvrigt opgive kulturbegrebets elitære, auratiske dimensioner. Der er ikke tale om, at Benjamin fornægter sin baggrund i tyvernes kulturelle miljø. Han beskæftiger sig til sin død i 1940, ikke alene med Marx, men forer hele menageriet af filologer og nyromantikere med sig, for at omfortolke og redde dem, faktisk for at være sikker på at redde dem. Vel faktisk for at lære hele deres Vorschein at kende, og endelig ikke forkaste dem for tidligt. Det ville være utænkelig for en marxistisk kulturkritiker, der har taget begrebet om det ikke-identiske med sig fra sin tidlige position. Et af Benjamins sidste breve til Adorno fra foråret 1940 handler om Hofmannsthal og Kafka, og i hans sidste værk, De historiefilosofiske Teser fra 1939, indgår som grundfigur for historieopfattelsen, billedet angelus nozus af den ekspressionistiske Klee. $^{22}$

\section{IV}

Benjamins skift fra kultur til politik foregår i adskillige tempi. Efter at have forladt den germanistiske produktionskreds i midten af tyverne, opholder han sig i Paris sammen med Franz Hessel, den tyske forfatter og forlagsredaktør, som han oversætter dele af Prousts Recherche sammen med. I denne periode stifter de bekendtskab med den franske surrealisme, og især med Aragons tidlige hovedværk, Le paysan de Paris fra 1926.

Hovedfiguren i Bonden fra Paris er, som titlen siger, en mand, der betragter Paris udefra, med fremmede øjne, som var han en bonde. Hans distancerede iagttagelser går imidlertid i to vidt forskellige retninger. I bogens første del, Passage de l'Opera, redder betragteren passagerne, der snart skal rives ned; han skriver deres historie, forhindrer deres glemsel, lige før den store byplanlægning jævner dem med jorden, til fordel for flere boulevarder. Der er især beskrivelser af de prostituerede, af androgyne badeanstalter, af samfundskritiske småborgere, der opfordrer til oprør mod magistraten gennem opslag i de halvmørke passager. Der er skildringer af småkriminelle og deres krinkelkroge og smutveje. Beskrivelsen forvandles langsomt til et bil- 
lede på det ubevidste, der for Aragon er identisk med det fællesmenneskelige, og står i modsætning til den bysanerende fornuft, der adskiller menneskene. Denne del af Aragon overtager/viderefører Benjamin og Hessel, men derimod ikke hans anden side, der kommer til udtryk i anden del af Bonden fra Paris: Le Sentiment de la Nature aux Buttes-Chaumont, foregår i storbynaturen, og skildrer en natlig udflugt for surrealister til Buttes-Chaumont- parken i udkanten af Paris. Her er gåturen ikke flanerie, ikke distanceret betragtning og redning af det fallesmenneskeliges fortrængte og truede erfaring, men derimod lovprisning af fremskridtet $\mathrm{i}$ en lyrisk-rusagtig bekendelse til teknik og tempo. Tanken er den, at samfund og industri er natur, naturen er menneskets ånd, der slumrer og skal vakkes til live gennem menneskets store bekendende $j a$ til teknikken som dæmoniseret og irrationel kraft. Her er den surrealistiske vandring erobring og samklang, ikke mimetisk redning. ${ }^{23}$

Et af Aragons hovedbegreber i Bonden fra Paris er den moderne mytologi. Med moderne mytologi mener han fælles erfaring, tankeformer, der ikke er rationelle, men snarere følger drømmens logik. Flanørens mission i denne verden er for Aragon at finde og at skabe eksempler på moderne mytologi. Det sker ved at opsøge ydmyge eller glemte steder, i udkanten af den sejrende, historiske udvikling (passagerne), eller i udkanten af offentligheden (natlig parkudflugt). Det er det reddende perspektiv at finde det glemte og subversive. De områder Aragon finder, finder han der hvor guderne er, og guderne har forladt søjlerne, siger han $\mathrm{i}$ indledningen til Opera-passagen:

\footnotetext{
Man tilbeder ikke mere guderne ovenover skyerne. Salomons tempel er kun en metafor, der giver ly til svalereder og farveløse firben. Kultens ånd har spredt sig overalt, de hellige steder er overladt til forfaldet. Men andre steder florerer hos menneskene, steder, hvor de ubekymret fører deres hemmelighedsfulde liv, hvor der efterhånden opstår en agte religion. Et sådant lys hersker underligt nok i hine overdakkede gallerier, som der findes flere af i Paris tat ved de store boulevarder, og som man fejlagtigt kalder passager, som om det i disse gange uden dagslys ikke var tilladt nogen at blive mere end et øjeblik. ${ }^{24}$
}

Denne side af den moderne mytologi indgår som ramme i Benjamins senere Passagearbejde, som en bestræbelse på at redde den konkrete, profane verden fra almenheden. Men den jasigende, teknikbegejstrede side af Aragon og Breton afviser Benjamin senere som et levn af idealistisk naturfilosofi, hvilket jo også er helt korrekt, idet der er tale om et genbrug hos Aragon af Schelling.

I slutningen af tyverne transformerer Benjamin og $\mathrm{Hessel}^{25}$ den franske surrealisme om til den centraleuropæiske horisont, i Benja- 
mins Berliner Chronik/Berliner Kindheit og i Spazieren in Berlin af Hessel fra 1929. Det er Hessels og ikke den franske surrealisme-version, som Benjamin lader sig lede af, dels i Berliner Kindheit, hvor Hessel omtales som Bonden fra Berlin, og i Passagearbejdet. Hessel er Benjamins ledsager og fører ham gennem det hemmelige Berlin. I bogen om Berlin af Hessel introduceres flanørmotivet straks som interesseløshed og iagttagelse, i modsætning til subjektiv fortolkning og beherskelse. Første kapitel handler om flanørens problemer, $\mathrm{i}$ en nytteverden, med mistænksomheden. Folk tror han er politispion, fra bevillingspolitiet, eller lommetyv, fordi han venter uden objekt:

A $t$ gå langsomt gennem beferdede gader, er en særlig fornøjelse. Man bliver løbet over ende af de andres hastværk, det er et bad i brændingen. Men mine kære berlinske medborgere gør det ikke let for en, selv om man går af vejen for dem nok så behændigt. Jeg må altid indkassere mistroiske blikke, når jeg forsøger at flanere mellem de travle. Jeg tror, man tager mig for en lommetyv. ${ }^{25}$

Sidste kapitel er bogens konklusion på flanørens tilfeldige vandringer i Berlin og Mark Brandenburg:

Vi berlinere må bebo vores by - meget mere. Det er slet ikke så let, både at betragte $\mathrm{og}$ bebo en by, der altid er undervejs, altid i færd med at blive anderledes og aldrig hviler ud $\mathrm{i}$ det forgangne... Byen sitrer mod fremtiden. ${ }^{26}$

Hessel har skrevet et erkendelsesteoretisk essay vedrørende Spazieren in Berlin: Om den vanskelige kunst at gå tur. Her er flanørens filosofi formuleret således, at den netop reflekterer den reddende del af Aragons moderne mytologi:

\footnotetext{
»Flanere, det gør man da ikke mere«, siger menneskene. »Det strider mod vor tids rytme«. Det tror jeg ikke. Netop den der - jeg kunne næsten sige: kun den der kan flanere, vil kunne nyde denne vores tid og forstå den... I enhver af os lever der en hemmelig lediggænger, der sommetider glemmer sine respektive bevæggrunde og găr af sted uden grund. Og lykkes det for ham, să vil gaden, netop fordi han kun betragter den, være elskværdig mod ham. Den bliver hans dagdrøm. Udstillingsvinduerne er ikke mere påtrængende tilbud, men landskaber; firmanavne, især dobbeltnavnene med $\&$ tegnet i midten, der ofte forbinder de kutroligste ting, bliver til mytologiske skikkelser, til eventyrpersoner. ${ }^{27}$
}

Først definerer Aragon passagerne, det der skal reddes, som drømmetilstand, der indeholder en subversiv, kollektiv-kommende dimension, en anden slags erfaring end den borgerlige fornuft. Derefter omgestalter Hessel og Benjamin den moderne mytologi, så den bliver en kritisk instans mod den form for borgerlig fornuft, der sætter det 
tekniske fremskridt og naturbeherskelsen absolut. Den moderne mytologi hos Hessel og Benjamin indeholder en særlig melankolsk refleksion, de opererer med et fremmedgørelsesbegreb overfor fremskridtet, der hindrer dem i at hylde det som en gud, i modsætning til futuristerne, surrealisterne, dele af den ny saglighed, kulturradikalismen mm. Men, mens surrealisterne og Hessel dyrker drømmetilstanden som sandhed og autentisk erkendelse, ja som surrealistisk modoffentlighed, så lader Benjamin drømmen indgå i en historisk-sociologisk analyse af det nittende og det tyvende århundredes udvikling. Drømmen skal bestå sin realitetsprøve, det er kun dens rationelle, revolutionære kerne, der skal reddes, og i den proces fjerner Benjamin sig afgørende fra den centraleuropæiske kulturs klassisk-romantiske perspektiv. Han gør sig til analytiker af sin tid, han er ikke kun indlevende, han er også diagnosticerende.

Dette er Benjamins marxistiske fase i trediverne, hvor han lever i eksil i Paris, og skriver Passageprojektet, om Paris i det nittende århundrede. Andet afsnit i Paris hos Baudelaire under det andet Kejserdømme handler om flanøren. Her er den iagttagende og medierende holdning imidlertid defineret som en særlig socialkarakter i det nittende århundrede; den er trukket ud af den bestemte, tidligere heroisk dyrkede, centraleuropæiske holdning. Benjamin læser i trediverne de særlige, centraleuropæiske dyder som almene, sociale træk i det nittende og det tyvende århundrede. Der er altså tale om, at han i trediverne overvinder en provinsialisme i sin tænkning. ${ }^{28}$

Flanøren i Passageværket er massemennesket i kapitalismens tidlige stadium. Han er endnu beruset af at betragte cirkulationen, vareverdenen, passagernes vareæstetik i Paris på Napoleon den 3. tid, og mængden omkring sig. Vareverdenen er for ham stadig forbundet med aura, med forjættelser, lysreklamer og skin. Men i det tyvende århundrede, siger Benjamin, med udagnspunkt i den politiske situation i trediverne, vågnede massemennesket op til truende proletarisering, fattigdom og bristede forhåbninger. Den kollek tivitet det flygter ind $i$, er nu den totalitære stats sammenhæng af massefascination og æsteticering af politik, især under fascismen i Tyskland og Italien. I lyset af den totalitære stats fødsel i det nittende og dens blomstring i det tyvende århundrede, ser Benjamin holdningen hos Baudelaire, Hofmannsthal, Benn og George som et billede på det politisk ambivalente massemenneske, med en utopi, der endnu befinder sig i drømmestadiet. Hvor Benjamins teori så skal vække den sovende til bevidsthed om sin situation og praksis, på samme måde som grækernes træhest står midt i nattens Troja. ${ }^{29}$

I lyset af den politiske udvikling i Sovjetunionen i tredivernes slut- 
ning, processerne og Hitler-Stalin-pagten, reaktiveres Benjamins gamle mistænksomhed overfor systemtænkningen og dens politiske magt og allestedsnærværelse. Hans arv fra den centraleuropæiske kultur, det ikke-identiskes betydning, foldes ud i en generel kritik af Marx-fortolkninger og historiesyn hos anden og tredie internationale. I de historiefilosofiske teser fra 1939 formulerer han en voldsom kritik af fremskridtstroen og totalitetssynet $\mathrm{i}$ den da eksisterende teori fra Bernstein til Stalin. Benjamins hovedtese er, at fremtiden skal skabes udfra den søndertrådte fortids håb, de forrådte revolutioner, de fejlslagne eksperimenter. Overfor marxismen i dens eksisterende former, taler Benjamin i Teserne udfra et virkelig utopisk begreb, om den sande marxist og marxisme, som dybest set er knyttet til et religiøst håb om pludselig forandring, om messiansk genkomst. Tesernes sidste sætning handler om jødernes syn på fremtiden:

Thi i den var hvert sekund den lille port, som Messias kunne træde ind $\mathrm{af}^{30}$

Intentionen i De historiefilosofiske Teser følges op af Horkheimer/ Adornos bog om Oplysningens Dialektik fra 1944, selvom de jo udvider Benjamins historisk ret præcise kritik til en kritik af europæisk, vesterlandsk historie fra Homer til i dag. Hos dem påbegyndes en rekurs til den centraleuropæiske tænknings ikke-identiske grundlag og kulturelle horisont, som især bliver tydelig hos den sene Adorno og hos de temmelig mange forfattere, der er påvirket af ham, Botho Strauss, Wolf Wondratschek, Ludwig Fels og først og fremmest Enzensberger. ${ }^{31}$ Den centraleuropæiske tankegang efter den anden verdenskrig er ikke kun et levn fra gamle dage, som Kundera har taget med sig fra Prag og markedsfort i Vesteuropa i disse nostalgiske tider.

\section{Noter:}

1. Milan Kundera er født i Brno 1929. Fra 1945 var han medlem af det kommunistiske parti, men blev ekskluderet i 1948. Han var professor ved det filmvidenskabelige institut i Prag i tresserne, men blev afskediget i 1968. Som forfatter năede han at udgive En spøg (1967) i Tjekkoslovakiet, men det øvige forfatterskab findes kun i oversættelser. Fra 1975 har Kundera opholdt sig i Vesteuropa/Paris. Han turde være et af de relativt få eksempler på en væsentlig udenlandsk forfatter, som meget hurtigt er blevet oversat til dansk, og hvis forfatterskab, og ikke kun enkelte bøger, faktisk foreligger, til og med hans essay om Romankunsten, som han har skrevet på fransk og ikke på bøhmisk.

Livet er et andet sted $1973 / 1977 \mathrm{da}$.

Afskedsvalsen $\quad 1972 / 1978 \mathrm{da}$.

Om latter og glemsel $1979 / 1980 \mathrm{da}$.

Tilvarelsens ulidelige lethed

1984/1985 da.

Romankunsten $\quad 1986 / 1987 \mathrm{da}$.

2. Se Romankunsten side 9-29. 
3. Med udgangspunkt i de tre nøglebegivenheder, 1938/1948/1968 udvikler Kundera tilbageskuende en teori om historisk udvikling som idyl, dvs. de historiske katastrofer tildækkes af tvangsharmoniseringer, kaldet glemsel. Prag er glemselens by, Kafka glemselens forfatter. Som en konsekvens af denne historieteori, der i sin medinddragelse af subjektet minder om Adornos definition af tingsliggørelse som glemsel, bliver historie til skæbne og subjektet til fiktion, til en imaginær størrelse. Se Romankunsten side 134 og 136, og ikke mindst side 149: "I Europa gennemlever vi nyere tids afslutning; afslutningen på individualismen; afslutningen på kunsten opfattet som udtryk for uerstattelig personlig originalitet; en afslutning, der indvarsler en epoke af uniformitet uden sidestykke. Denne fornemmelse af afslutning finder man ikke i Amerika... der kun er nyere tids sildefødte arving."

4. Se Romankunsten side 138.

5. Moderne kunst kan ifølge Kundera være Kitsch, hvis dens modernitet er følgagtighed og forherligelse af fremskridtet, teknikken osv. Et eksempel er Apollinaire. Men heroverfor står Kafkas:

»antilyriske, antiromantiske, skeptiske, kritiske modernisme. Med og efter Kanka: Musil, Broch, Gombrowicz, Beckett, Ionesco, Fellini... « Romankunsten side 146.

6. Udsendelse i DR, om centraleuropa. Kultur, 5.7.87.

7. Romankunsten side 132 .

8. Da Buch vom Lachen und Vergessen, Suhrkamp 1980, side 212.

9. Romankunsten side 9-29.

10. Romankunsten side 140, Das Buch vom Lachen und Vergessen side 246.

11. Selvom Tomas og T:resa er indfanget af den store idyls uundgåelighed, så handler romanens slutning samtidig om en anden, imaginær idyl, nemlig deres skrøbelige og foreløbige tilvarelse $\mathrm{i}$ historiens afkrog. Der er tale om to vidt forskellige utopi-forståelser hos Kundera: en officiel, byggende på det historiske fremskridts forjættelser og katastrofiske slutparadoks. Og heroverfor en æstetisk-sporadisk, en øjeblikkets utopi midt i fremskridtet, og uden konsekvenser for fremskridtets kvalitative ændring. En sådan øjeblikkets utopi er skildret $\mathrm{i}$ dansescenen, der slutter Tilværelsens ulidelige Lethed. (side 256rf.). Som et udtryk for denne dobbeltbestemmelse af utopi, kan også Kunderas dobbeltbrug af ord og begreber betragtes. Lethed slår om i tvang (slutparadoks), men der findes også subjektets lettelse over at have rystet historien af sig et xjeblik. Idyl er Kitsch, men også Tomas' og Teresas frihed på landet. Engel er lovprisningen af hierarkiet og samtidig den befriende engel i Bogen om Latter og Glemsel.

12. Kitsch er Kunderas ( $\mathrm{Og}$ Brochs) nøgleord for historiens tendenser til at idyllisere sine løbende katastrofer. Kitsch er ikke pop eller massekultur, men al symbolsk kunst. Se Romankunsten side 138.

13. I Bogen om Latter og Glemsel kalder Kundera sin romanteknik for Variation, dvs. beskrivelse af verden $\mathrm{i}$ overraskende og nye konstellationer. I hele sin reflekterende, essayistiske grundholdning bekender Kundera sig til det attende århundredes oplysningstradition hos Diderot og Sterne:

„Romanforfatteren gør intet større væsen af sine ideer. Han er opdagelsesrejsende, der famlende bestræber sig på af afdække et hidtil ukendt aspekt af tilværelsen.« (Romankunsten side 151).

14. Også Freud indgår i denne sammenhæng, i sin kortlægning af det ubevidstes lovmæssighed, og i sin bestræbelse pă at indsætte jeg i id'ets sted. Hos Kundera slås Freud uden videre sammen med tyvernes store fiktionsforfattere:

»De største ånder (Freud, romanforfatterne) genopskriver det, der igennem århundreder havde været miskendt og ukendt: den afmystificerende, rationelle klarhed, sansen for virkeligheden, romanen. Deres oprør står i diametral modsætning til den franske modernismes revolte, der er antirationalistisk, antirealistisk, lyrisk « (Romankunsten side 129). Fællesnævneren mellem romanforfatterne og Freud skulle så være forsvaret for jeget, i dets kritiskskeptiske form fra det attende århundrede. Ganske vist tyder Freuds stærke forbehold 
overfor surrealisternes brug af hans Drømmetydning til at hylde det ubevidste, på den modsæetning som Kundera taler om. Alligevel rejser modstillingen en række spørgsmåt. Strabte romanforfatterne og Freud virkelig efter samme type virkelighed? Og var mange af de centraleuropæiske forfattere, Brochs mystik eksempelvis, ikke mindst lige så lyriske og musikalske som Apollinaire og Aragon?

15. Carl E. Schorske, Fin de Siècle Vienna - Politics and Culture. New York 1980. Side 19ff.

16. Hugo von Hofmannsthal, Ausgewählte Werke in zwei Bänden. Fischer 1966. Bd. II, side 337-48.

17. Se Manfred Frank: Auf der Suche nach einem Grund. Über den Umschlag von Erkenntniskritik in Mytologie bei Musil. I: Mythos und Moderne, Hrg. Karl Heinz Bohrer, Suhrkamp Edition 1983.

18. Robert Musil, Nachlass zu Lebzeiten. I: Ges. Werke, Bd. 7, side 476.

19. Robert Musil, Bd. 8. Side 1078.

20. Robert Musil, Manden uden Egenskaber, bd. 2, side 384-85. Kbh. 1969.

21. ibid., bd. 1, side 1 lff.

22. Henning Goldbæk: Ernst Bloch: En utålmodig kulturkritiker. Efterord til: Bloch: Spor. Kbh. 1985.

Henning Goldbæk: De tavse sireners sang - om forholdet mellem digtning og filosofi hos den tidlige Walter Benjamin. Kbh. 1987. Konferensspeciale, manus.

23. Louis Aragon, Le paysan de Paris, Gallimard 1984, side $176 \mathrm{ff}$.

24. Aragon, ibid., side 19.

25. Franz Hessels forfatterskab omfatter blandt andet romantrilogien Der Kramladen des Glücks (1913), Pariser Romanze (1920) og Heimliches Berlin (1927). Desuden Spazieren in Berlin (1929), genudgivet 1984 som Ein Flaneur in Berlin. Endelig essaysamlingen Ermunterungen zum Genuss (1933), og den ufuldendte roman Alker Mann (1941) Det var især Hessels »blide surrealisme«, hans flanørtema, der optog Benjamin; Hessels distancering fra den økonomiske formålsbetragtning, til fordel for de tilfældige vandringer, hvor flanøren uden et bestemt formål læser storbyen, som ord, sætninger og sider i en stadig ny bog.

26. Hessel, Ein Flaneur in Berlin, Arsenal 1984, side 7.

27. Hessel, ibid., side 275.

28. Hessel, Ermunterung zum Genuss, Brinkmann \& Bose 1981, side 54

29. Walter Benjamin, Gesammelte Schriften, Suhrkamp, Bd. I.2, side 629ff.

30. Walter Benjamin, Gesammelte Schriften, Suhrkamp, Bd. V.2.

31. Walter Benjamin, Gesammelte Schriften, Bd. I.2, side 704.

32. Hvor Enzensberger omkring 68 fravalgte lyrikken til fordel for politisk praksis og tidsskriftsaktivitet, revolutionsturisme $\mathrm{mm}$., så er hans senere forfatterskab præget af nøjagtig samme skepsis og essayistiske grundholdning som hos Kundera og den ældre tradition. I Mausoleum, Titanics Undergang, og i Forsvindingens Furie. Den nye holdning kommer blandt andet til udtryk $i$ et digt fra 1971:

Et sidste bidrag til spørgsmålet om litteratur?

Kære kollegaer, jeg forstår jer ikke.

Hvorfor citerer I ustandselig Hegels æstetik og Lukaćs?

Hvorfor orienterer I jer dag efter dag.

Efter det historiske niveau?

Hvorfor ærgrer I jer over det

der står i Kursbuch?

Hvad skyldes denne angst for at blive klassiker

eller det modsatte?

Og hvorfor er I bange

for at være klovne?

for at tjene folket? 